\title{
Tekst w kulturze, kultura w tekście. Tradycja łacińska i literatura staropolska w Spowiedzi Calka Perechodnika
}

Zamierzam przedstawić dwa problemy: pierwszy dotyczy funkcjonowania pamiętnika Calka Perechodnika w kulturze ponowoczesnej, drugi - obecności tradycji łacińskiej i staropolskiej w Spowiedzi. W moim przekonaniu oba te zagadnienia - wbrew niektórym współczesnym interpretacjom - łączą się i odwołują do wspólnego paradygmatu. Zarówno tekst Perechodnika, jak $\mathrm{i}$ świat $\mathrm{w}$ nim przedstawiony mieszczą się $\mathrm{w}$ tym paradygmacie i dają się odczytywać według tych samych fundamentalnych zasad kultury europejskiej: etyki i estetyki.

\section{Tekst o Zagładzie w kulturze ponowoczesnej}

Mimo iż w odniesieniu do wielu świadectw czasów Zagłady stosuje się określenia: „najważniejsze”, „najwybitniejsze” " to w przypadku Spowiedzi opinia taka wydaje się wyjątkowo trafna. Podzielam pogląd wyrażony przez Zbigniewa Gluzę:

Wielu badaczy i komentatorów gotowych jest uznać, że Spowiedź Calka Perechodnika okazuje się najwybitniejszym tekstem, jaki zachował się z czasu Zagłady. Autor bowiem zostawił po sobie nie tylko stanowczy akt oskarżenia, ale zarazem - przenikliwą spowiedź. Sam

I Samo określenie, że jakiś tekst jest najwybitniejszym lub najważniejszym świadectwem Zagłady, dzisiaj ma już przede wszystkim charakter reklamowy, a więc czysto komercyjny. Oto na okładce książki Primo Leviego Czy to jest człowiek (przeł. H. Wiśniewska, Kraków 2008) czytamy: „[...] obozowe wyznanie Primo Leviego uważane jest dziś za najważniejsze w literaturze światowej świadectwo Zagłady". W swego rodzaju licytacji, co jest owym najważniejszym świadectwem, pobrzmiewa coś nieprzyzwoitego! Wszystkie dokumenty i dowody Zagłady są jednakowo ważne (choć oczywiście różnią się pod wieloma względami, między innymi poziomem artystycznym). 
z poczuciem winy, czyni ze swego losu przedmiot namysłu bezkompromisowego, wiwisekcji bez warstwy ochronnej ${ }^{2}$.

Wskazana przez wydawcę właściwość tekstu, owa „wiwisekcja bez warstwy ochronnej”, stała się (prawdopodobnie) przyczyną powikłanych losów wydawniczych pamiętnika, które David Engel opisał tak:

[...] w 1993 roku ukazały się wspomnienia Calela Perechodnika, pod tytułem Czy ja jestem morderca? Niestety to pierwsze polskie wydanie, jak i kolejne z roku 1995, zawierały istotne odchylenia od oryginalnego tekstu pamiętnika. W obydwu opublikowanych wcześniej polskich wydaniach brakuje wielu zdań, a nawet całych ustępów, obecnych w rękopisie, a wiele fragmentów zostało całkowicie przerobionych ${ }^{3}$.

To dzięki skrupulatnej pracy edytorskiej Davida Engela „polski czytelnik może zapoznać się z tekstem Perechodnika w całości, w brzmieniu takim, jak go zapisał sam autor w melinie na ulicy Pańskiej w czasie od 7 maja do 19 października 1943" 4. Wydaje się, że ów brak „warstwy ochronnej” - inni wolą mówić o „prawdziwym i jednocześnie zakłamanym” charakterze tego pamiętnika - spowodował wiele kłopotów $\mathrm{z}$ analizą $\mathrm{i}$ interpretacją Spowiedzi. Jak różne mogą być odczytania tekstu Perechodnika, niech zaświadczy zestawienie dwóch opinii - najpierw Gustawa Herlinga-Grudzińskiego:

Pamiętnik Perechodnika, policjanta żydowskiego w otwockim getcie, jest dotknięciem [...] dna absolutnego. Człowiek kulturalny i wykształcony, inżynier rolnik po studiach we Francji, pomaga jako policjant załadować do wagonu Zagłady żonę i uwielbianą córeczkę. Byle chwilowo ocaleć. „Czy ja jestem mordercą?” - pyta. Mordercą nie, gorliwym pomocnikiem mordu tak. Gdyby rozumiał, że istnieje coś gorszego jeszcze od śmierci, pojechałby do Treblinki razem z żoną i dzieckiem. Wybrał mały, nędzny ochłap życia (na więk-

${ }^{2}$ Z. Gluza, Od wydawcy, w: C. Perechodnik, Spowiedź, oprac. D. Engel, Warszawa 2011, s. 5. Cytaty zaczerpnięte z tej edycji tekstu oraz inne nawiązania do niej są oznaczone dalej w nawiasach, gdzie podawany jest numer strony.

3 D. Engel, Postowie, w: C. Perechodnik, op.cit., s. 322-323.

4 D. Engel, op.cit., s. 323. Na szczęście nie sprawdziła się przepowiednia sformułowana między innymi przez Izabellę Sariusz-Skąpską: „O tym pamiętniku napisano kiedyś, że na zawsze pozostanie w rękopisie, ponieważ ani Polacy, ani Żydzi nie odważą się opublikować wspomnień tak przepojonych nienawiścią do ich narodów”. I. Sariusz-Skąpska, Wybrani, naznaczeni, przeklęci..., „Znak” 1994, nr 6, s. 76. 
szy nie mógł liczyć). O resztce jego życia resztkami człowieczeństwa lepiej zamilczeć. Z pobudek miłosierdzia. Opowiada o swoich dwóch „zarobionych” latach z pełną świadomością tego, co zrobił i co „zarobił”. Trzeba zadawać sobie gwałt, żeby dobrnać do ostatniej stronicy tego pamiętnika „pokuty”, prawdziwego i równocześnie zakłamanego 5 .

A następnie Michaela C. Steinlaufa:

Wspomnienia, których autor nie przeżył wojny, leżały niepublikowane przez blisko pół wieku w Żydowskim Instytucie Historycznym. Przedstawiają wyjątkowy, nieubarwiony obraz pozbawionego heroizmu świata kompromisów moralnych. Dowiadujemy się z nich o Polakach chciwie wyczekujących na majątek po żydowskich sąsiadach, a później okradających ciała zmarłych, o Żydach wyrzucających własnych krewnych z przeludnionych kryjówek i o samym Perechodniku, który dał się oszukać niemieckim zwierzchnikom i zawiózł swoją żonę i córkę do transportu śmierci, a sam zdołał go jednak uniknąć $c^{6}$.

Czytelnik, który nie zna tekstu Perechodnika, ma - uzasadnione - prawo zapytać, czy aby na pewno Herling-Grudziński i Steinlauf piszą o tym samym pamiętniku? Polski pisarz czyta tekst Perechodnika przede wszystkim jako świadectwo losów człowieka, który podjął współpracę z aparatem terroru systemu totalitarnego i za tę współpracę zapłacił całkowitą utratą człowieczeństwa. Dla interpretacji Herlinga-Grudzińskiego punktem odniesienia są jego osobiste doświadczenia związane $\mathrm{z}$ losami jednostek zaplątanych w tryby machiny zbrodniczej systemu sowieckiego. To właśnie dlatego, że polski pisarz przeszedł przez piekło sowieckich łagrów i widział na własne oczy wszelkie stopnie człowieczego upodlenia, postawa Perechodnika nie budzi $\mathrm{w}$ nim cienia sympatii. I właśnie dlatego, a nie $\mathrm{z}$ jakichś innych powodów (na przykład dlatego, że jest tylko intelektualistą, który zza biurka wystawia oceny moralne), Herling-Grudziński jest tak zasadniczy w swej diagnozie. Rzeczywiście jest, jak pisze Maria Janion, „bezwzględnym moralistą, którego dławi pogarda i nie odczuwa dostatecznej litości" ". Polski pisarz - według mnie - ma jednak prawo do takich ocen, bo „tam był, widział i to przeżył”.

5 G. Herling-Grudziński, Dziennik pisany noca 1993-1996, s. 255.

${ }_{6}$ M.C. Steinlauf, Pamięć nieprzyswojona. Polska pamięć Zagłady, przeł. A. Tomaszewska, Warszawa 2001, s. 149.

7 M. Janion, Ironia Calka Perechodnika, w: eadem, Bobater, spisek, śmierć. Wykłady żydowskie, Warszawa 2009, s. 264. 
Przecież - zbyt często się o tym zapomina - sam Perechodnik też nie odczuwał litości i okazywał pogardę zarówno wobec siebie, jak i wobec innych policjantów żydowskich:

Zostaje wydany rozkaz policji żydowskiej dostarczenia ludzi na plac. Policjanci w liczbie 2000 ludzi, zabierają się energicznie do roboty. Każdy winszuje sobie, że miał rozum zapisać się do policji, spokojny o siebie, o swoją rodzinę, pewny, że przy takiej okazji szafa mu zagra, zabierze się do dzieła. Przede wszystkim rozbijają sklepy żywnościowe, żeby uratować towar, żeby samemu z rodziną nie głodować. Już odtransportowano biedaków z ulicy, z punktów, aresztantów, przychodzi kolej na sierocińce. Jeśli kogoś sumienie dręczy, to zagłusza wódką. Dzień prędko mija. (s. 42)

Ponadto autor Spowiedzi wielokrotnie sam występuje w roli „bezwzględnego moralisty”, na przykład kiedy pisze:

Nie ma żadnego usprawiedliwienia dla policji żydowskiej w Warszawie, nie mogą się bronić, tłumacząc, że działali w zamroczeniu umysłu. Tak można działać przez jeden dzień, ale nie przez długie trzy miesiące. Przez ten czas zatwardziały im serca, obce stały się im wszelkie uczucia ludzkie, rabowali, łapali ludzi, na rękach wynosili z mieszkań niemowlęta, które matki zostawily, bo nie mogły ich brać ze sobą do piwnic, do rozmaitych schowków. Żydowscy policjanci brali te maleństwa i dostarczali Ukraińcom. Nic dziwnego też, że Żydzi znienawidzili swoją policję więcej od Niemców, bardziej od Ukraińców. (s. 154)

Wydaje się, że jedyne, co mogą zrobić współcześni interpretatorzy tekstu Perechodnika, którzy nie przeżyli Zagłady - a do takich należy piszący te słowa - jest krytyczne zestawienie źródeł i wyciąganie wniosków. Wprowadzanie wszelkiego rodzaju relatywizmów, czy też wskazywanie na „niewspółmierność” i odrzucanie klasycznych kryteriów moralnych, jest w najlepszym wypadku zwykłym unikiem, a w najgorszym - hipokryzją i próbą obrony czyichś nieetycznych uczynków. Właśnie w celach obrony Perechodnika tak ostro krytykuje się moralistów, jakby w odniesieniu do literatury o Zagładzie tradycyjny kodeks moralny był bezużyteczny, a każdy moralista stawał się personą wielce podejrzaną, którego największym błędem jest wyraźne dwubiegunowe widzenie ludzkich działań i postępków. Moralistów potępia nie tylko Maria Janion, podobną opinię wygłosił także między innymi Jarosław Ławski: „Moralista, poszukujący dwubiegunowej, dystynktywnej wiedzy o świecie, «prawdy», którą rozpo- 
znaje się przez «szablon» Dobra/Zła, otóż taki czytelnik odrzuca autora i dzieło [...]. Przy czym to odrzucenie może być dziełem

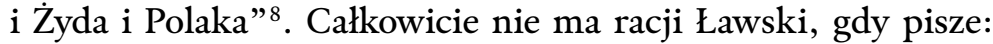
„Kiedy Perechodnik wstępuje do policji w getcie, z nim, w owych okolicznościach, których nie mamy prawa sądzić czy wybaczać, znajduje się ta część tradycji, dziedzictwa kultury polskiej, jaką ujawnia na kartach «pamiętnika»" 9 . Jestem głęboko przekonany, że „mamy prawo sądzić” i niezależnie od tego, jak górnolotnie i nieponowocześnie to zabrzmi, mamy prawo sądzić w imię pamięci, oddania sprawiedliwości i szacunku tym wszystkim, którzy nie ulegli, nie współpracowali, nie upodlili się i zapłacili najwyższą cenę. To Hannah Arendt miała rację, kiedy „W notatkach do wykładu wygłoszonego na Uniwersytecie Wesleyan [...] napisała «Jeśli mówicie sobie w takich sprawach $^{\mathrm{Io}}$ : kim jestem, aby osądzać? - już przegraliście»" ${ }^{\text {II }}$. Powstrzymywanie się od ocen (pozytywnych lub negatywnych), czy wręcz ich zakazywanie, wydaje się podszyte ideą niewspółmierności. O konsekwencjach stosowania tej idei w odniesieniu do Cynthii Ozick i jej uwag dotyczących Dziennika Anny Frank napisał Lindsay Waters:

Nie-Żydzi nie powinni nawet ośmielać się myśleć, że rozumieją w najmniejszym stopniu, co przydarzyło się Żydom w czasie holokaustu. Moralna otucha odczuwana przez nie-Żydów, którzy myślą, że mogą współczuć Annie Frank, wzbudza w Ozick obrzydzenie i prowadzi do wniosku [...] myśli, że świat byłby lepszy, gdyby dziennik został „spalony, zgubiony lub gdyby przepadł”. Ta myśl skłania [...] do zastanowienia się, czy Hitler rzeczywiście nie wygrał tej wojny. Umarł, ale jego wola zwyciężyła, wola siania wiecznej wrogości między narodami, które pozwalają sobie na konstytuowanie się w sposób, jaki mu odpowiadał: jako więźniów tożsamości ${ }^{\mathrm{I} 2}$.

Jeśli powstrzymamy się od oceny czynów Perechodnika, także ocena czynów odrzucających współpracę i współudział w zbrodni, których dokonały setki tysięcy tzw. zwykłych ludzi, również

${ }^{8}$ J. Ławski, Narracja i, „wyniszczenie”. O spowiedzi Calka Perechodnika, w: Stosowność i forma. Jak opowiadać o Zagładzie?, red. M. Głowiński et al., Kraków 2005, s. 151. Tekst ten ukazał się także w „Tekstach Drugich” 2005, nr 4, s. $173-195$.

9 J. Ławski, op.cit., s. 154.

ro Chodzi o ocenę postępowania przywódców Judenratów.

II Cyt. za: D. Lipstadt, Proces Eichmanna, przeł. M. Antosiewicz, Warszawa 2012, s. 201.

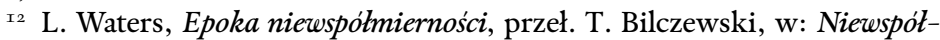
mierność. Perspektywey nowoczesnej komparatystyki, red. T. Bilczewski, Kraków 2010, s. 75. Zob. też s. 80 . 
traci na jednoznaczności i może - powtarzam: może - być interpretowana jako nic nieznaczące, puste gesty.

Powracam do zasugerowanej na początku opozycji dotyczącej różnych, często skrajnych odczytań Spowiedzi. Steinlauf dostrzega w tekście Perechodnika przede wszystkim świadectwo relacji polsko-żydowskich w czasach Zagłady. Tego rodzaju interpretacja jest - mówiąc najbardziej ogólnie - znacznym uproszczeniem. Steinlauf praktycznie stracił z pola widzenia Niemców, w jego interpretacji są tylko źli Polacy, prześladowani Żydzi i jeszcze jacyś „,niemieccy zwierzchnicy”, o których nic więcej nie wiadomo. A przecież Spowied ź ma trzech głównych „bohaterów”, im to właśnie tekst został dedykowany:

\section{S.N.}

P.P.

T.Ż.

Pamiętniki me poświęcam ${ }^{\mathrm{I} 3}$.

\section{Maria Janion uważa, iż przez tego rodzaju dedykację}

Calek Perechodnik od razu na początku określił [...] trzech protagonistów tragedii żydowskiej: Niemców, Polaków i Żydów oraz przypisał przysługujące im - w jego mniemaniu - cechy naczelne. Cała siła wściekłej ironii autora kieruje się dokładnie przeciw tym trzem czynnikom sprawczym mordu, dla którego nie znajduje on żadnego usprawiedliwienia ${ }^{\mathrm{I}}$.

Jeśli nie budzi wątpliwości stwierdzenie Marii Janion o „trzech protagonistach tragedii żydowskiej”, to już dalsze uwagi muszą wywołać mniejsze lub większe zastrzeżenia. Po pierwsze, Janion przypisuje chyba zbyt wielką rolę ironii w tekście Perechodnika nie jest to zasada konstruująca cały tekst, ale przede wszystkim jeden $\mathrm{z}$ tropów myślowych ${ }^{\mathrm{I}}$. Mówiąc inaczej, ironia nie wystę-

I3 „Na podstawie rozmowy z Genią, z którą ukrywał się autor, jego brat Pejsach Perechodnik odszyfrował S.N. jako «sadyzmowi niemieckiemu», P.P. jako «polskiej podłości», T.Ż. jako «tragedii żydowskiej». Natomiast na podstawie tekstu można przypuszczać, że skrót T.Ż. powinien być odczytywany «tchórzostwu żydowskiemu»" (s. 7).

${ }^{I} 4$ M. Janion, op.cit., s. 261.

I5 Musimy pamiętać, że czym innym jest ironia jako trop, a czym innym jako figura myśli. „Ironia jest tropem wówczas, gdy mamy do czynienia w rzeczywistości jedynie z prostą, werbalną immutacją łatwo rozpoznawalną za pomocą kontekstu [...]. Ironia staje się figurą myśli, gdy jej istotą jest szersza konceptualna całość, często rozbudowana formalnie i skomplikowana myślowo, tak iż fragmentami sens ironiczny jest nawet trudno wyczuwalny [...]” (Z. Samolewicz, T. Soł- 
puje tu na poziomie inwencyjnym czy dyspozycyjnym tekstu (nie jest zasadą stanowiącą o strukturze całego pamiętnika), jest przede wszystkim reprezentowana na poziomie elokucyjnym, czyli że jest „werbalną immutacją łatwo rozpoznawalną za pomocą kontekstu". To właśnie będę się starał wykazać w drugiej części artykułu. Perechodnik znakomicie posługuje się ironią jako chwytem stylistycznym, ale jego relacja jest opowieścią bez żadnych osłonek, oskarżeniem wypowiadanym wprost, gorzką prawdą o zachowaniu się ludzi - Żydów, Polaków i Niemców w czasach Holocaustu. Dlatego w moim przekonaniu poważne wątpliwości budzi choćby takie stwierdzenie Tomasza Żukowskiego:

Niezwykłe jest też narzędzie, którym się posługuje [Perechodnik M.S.]: ironia. Ironiczny temperament wyostrza jego spojrzenie i pozwala rozpoznać mechanizmy dyskursywne, organizujące przestrzeń, w której porusza się polski Żyd. To one odpowiadają za konstruowanie faktów, porządkowanie rzeczywistości i jej interpretacje. Tak powstaje obraz, w którym przegląda się polska społeczność. Żyd istnieje w nim na sposób akceptowany przez większość, a reakcje na to, co spotyka go ze strony polskich współobywateli, muszą mieścić się w zakreślonych ramach ${ }^{\mathrm{I}}$.

Szkoda, że Autor nie wyjaśnia, na czym polega „niezwykłość ironii” w Spowiedzi, wszak Perechodnik był znakomicie wykształconym Europejczykiem, a więc znał podstawy poetyki i retoryki. Wypowiedź Żukowskiego na temat niezwykłości ironii budzi wątpliwości nie tylko moje, wydaje się kłócić także ze stwierdzeniem Magdaleny Kowalskiej: „Ironia, czy raczej dyskurs ironiczny nie dominuje wcale w literaturze dotyczącej czasów Zagłady, a jednak przejawia się przez rozmaite utwory" ${ }^{{ }^{7}}$. Nawet gdyby przyjąć hipotezę o dominacji ironii w tekście Perechodnika, to dlaczego $\mathrm{w}$ tak skonstruowanym obrazie miałaby się przeglądać tylko „polska społeczność” A czy to „przeglądanie się" nie dotyczy także społeczności żydowskiej? A gdzie się właściwie podziali Niemcy? Trudno nie odnieść wrażenia, że stworzony przez Tomasza Żukowskiego, ale nie przez Calka Perechodnika, „obraz” służy tylko jednemu: oskarżaniu

tysiak, Składnia łacińska, oprac. K. Bielawski, A. Gorzkowski, Kraków 2006, s. 256). Uważam, iż w Spowiedzi występują przede wszystkim ironie tropy.

${ }_{16}$ T. Żukowski, Savoir-vivre. Ironiczne strategie w „Spowiedzi” Calka Perechodnika, „Teksty Drugie” 2010, nr 6, s. 38.

${ }_{7}$ Zob. M. Kowalska, Ironia jako strategia narracyjna w opisach świata Zagłady, w: Stosowność i forma, s. 33. 
Polaków ${ }^{\mathrm{I}} \mathrm{i}$ całkowitemu pomijaniu dwóch pozostałych głównych bohaterów zbiorowych Spowiedzi - Żydów i Niemców.

Perechodnik nie jest pisarzem ponowoczesnym, w twórczości którego ironia to jedna (a może jedyna?) z czterech najważniejszych figur retorycznych ${ }^{19}$. Nie jest też prawdą - powracam do wypowiedzi Marii Janion - że w całym pamiętniku, nie tylko w dedykacji, trzem narodom Perechodnik ,przypisał przysługujące im [...] cechy naczelne”. Wielką zaletą autora Spowiedzi jest fakt, że w odniesieniu do Polaków stara się unikać wszelkiego rodzaju krzywdzących uogólnień typu „wszyscy Polacy to...”:

Prawda, Polacy pomagali mnie, ojcu, matce, pomagali i innym tysiącom Żydów, którzy jeszcze żyją. Nie chcę się okazać niewdzięcznym wobec nich i dlatego zmieniam moje nastawienie, więcej nie będę już mówić o Polakach i o ich stosunku wobec Żydów, ale będę pisać o panach X, Y, Z itd. Do każdego dobrego uczynku dodam nazwisko człowieka; opowiadając o każdym podłym uczynku - również wymienię nazwisko $^{20}$. (s. 151)

Autor Spowiedzi pisząc o zmianie postaw, przynajmniej niektórych naszych rodaków, przedwojennych antysemitów, wyraźnie wskazuje, że: po pierwsze, antysemitą nie jest się raz na zawsze; po drugie, czym innym był przedwojenny antysemityzm polski, a czym innym był niemiecki prowadzący do Holocaustu $^{2 \mathrm{r}}$ :

I8 Tomasz Żukowski pisze nawet o tym „co by było, gdyby”, czyli: „Gdyby trafił na polskie uniwersytety...”, Perechodnik nie studiował na polskiej uczelni. Otwarte pozostaje pytanie, po co zostały przywołany polski numerus clausus, z którym Perechodnik nie miał nic wspólnego. Według tej zasady interpretacyjnej Żukowski mógł przytoczyć w swoim artykule także wielowiekowe prześladowania Żydów w Polsce - zob. T. Żukowski, op.cit., s. 39.

I9 Czytając niektóre interpretacje pamiętnika Calka Perechodnika, można odnieść wrażenie, że ich autorzy chyba trochę na siłę próbują dostosować uwagi Paula de Mana do tekstu Spowiedzi. Jak pamiętamy, dla Paula de Mana najważniejszym tropem była ironia, którą nazywa „tropem tropów”.

${ }_{20}$ W edycji opartej na maszynopisie pamiętnika fragment ten został skrócony i brzmi tak: „Prawda, Polacy pomogli mnie, ojcu, matce - pomogli tysiącom innych Żydów. Myśląc o podłych, nie należy wyciągać wniosków dotyczących ogółu”. C. Perechodnik, Czy ja jestem mordercą?, oprac., posłowie, przypisy P. Szapiro, Warszawa 1995, s. 154.

${ }^{2 I} \mathrm{Na}$ różnice między polskim a niemieckim antysemityzmem wskazał między innymi Aleksander Wat: „[...] drugi [Niemiec - M.S.] miał furię niemiecką, bardzo dużo mówił. Straszny antysemita. Już po nim można było się domyślić, do czego może dojść w Niemczech. Nie typu polskiego, gdzie «gudłaj-żydziunio», tylko typu - rżnąć. Nie rżnąć, wytępić. Jeżeli Żydów palono, to dlatego, że szkoda noża na Żydów, nie mówiąc już o kuli. To jest ten niemiecki antysemityzm. Wytrzebić ogniem, wypalić”. A. Wat, Mój wiek. Pamiętnik mówiony, cz. 2, 
Jak [...] zareagowali antysemici przedwojenni [na Zagładę - M.S.]? Bardzo charakterystyczny jest wypadek z braćmi X. Pochodzili oni ze środowiska religijnego, katolickiego, przed wojną byli studentami, zagorzałymi przeciwnikami Żydów, z którymi kontaktu towarzyskiego nie utrzymywali i których zwalczali przy użyciu wszelkich środków, ale z grubsza nie kolidujących z zasadami wiary katolickiej. Dla nich Żyd był bogaczem, który wyzyskiwał pracę polską, był bogatym i mocnym przeciwnikiem, godnym walki. [...] Ale czasy się zmieniły, wspólny wróg zapanował nad Polską, prawda - podjudza Polaków na Żydów, ale czy to ma znaczenie wobec faktu, że przecież Polacy stracili swe niepodległe państwo. Teraz wziął się Niemiec za wytępienie Żydów; jakie stanowisko zajmują Bracia X? Czy się cieszą? Bynajmniej, Niemiec, ich odwieczny wróg, zabija ich współobywateli, zabija mężczyzn, żołnierzy frontowych, którzy krew swą przelali w obronie Polski, zabija dzieci, przyszłych budowniczych zrujnowanej i zniszczonej wojną Polski. Nie mówiąc już o tym, że ich serca ludzkie, prawdziwa wiara katolicka wznosi jeden głośny protest przeciwko takiemu barbarzyńskiemu postępowaniu. Toteż zmieniają zupełnie swe nastawienie, odzywa się w nich tendencja dawnej rycerskości i szlachetności polskiej, bezinteresownie w miarę możności ratują Żydów znajomych, jak i nieznajomych. Chylę czoła przed Wami, Bracia X, bynajmniej nie powinniście się wstydzić, żeście przed wojną byli antysemitami, tym ładniejsze jest Wasze obecne postępowanie. W tak ciężkich i niewdzięcznych czasach postąpiliście jak prawdziwi uczniowie Chrystusa, jak prawdziwi patrioci polscy. Cześć Wam! ${ }^{22}$. (s. 148-149)

rozmowy prowadził i przedmową opatrzył C. Miłosz, do druku przygotowała L. Ciołkoszowa, Warszawa 1990, s. 187.

${ }^{22} \mathrm{~W}$ poprzedniej edycji (opartej na maszynopisie) ten długi fragment dotyczący zachowania przedwojennych antysemitów w czasie Holocaustu znacznie został skrócony, choć jego przesłanie pozostało bez zmian (zob. C. Perechodnik, Czyja jestem mordercą?, s. 152). Nie do końca jest prawdą, że wersja maszynopisowa została poddana redakcyjnej obróbce łagodzącej tylko „antypolską” wymowę tekstu: skrócono też „propolskie” opinie, szczególnie te, które podważały schematy myślowe dotyczące polskiego antysemityzmu. Można zaryzykować twierdzenie, że praca redakcyjna polegała na tym, aby Polaków przedstawić zarówno nie jako niezbyt złych i niezbyt dobrych. W odniesieniu do Żydów redakcja tekstu polegała na wycieniowaniu lub usunięciu najbardziej „czarnych” i negatywnych opinii. Oto jeden z przykładów: Calek Perechodnik napisał: „, [...] partia żydowska «sprzątnęła» prawie wszystkich Żydów-gestapowców. «Wyrokiem Sądu Specjalnego za zbyt gorliwą współpracę z Niemcami» zostali rozstrzelani komendant policji żydowskiej [Józef] Szeriński, wicekomendant adw. [Jakub] Lejkin oraz wielu innych funkcjonariuszy żydowskiej policji” (s. 224-225). W edycji opartej na maszynopisie (C. Perechodnik, Czy ja jestem mordercą?, s. 204) zamiast „Żydów-gestapowców” użyto terminu „żydowscy współpracownicy Gestapo”. Takie przekształcenie terminologiczne pokazuje, jak trudne do przyjęcia było i jest określenie „Żyd-gestapowiec”. Terminem „Żyd-gestapowiec” Perechodnik posługuje się przynajmniej jeszcze raz (zob. s. 268), z kolei w wersji wcześniej- 
Perechodnik nie ma jednak złudzeń, że tego rodzaju postawy i zachowania wśród przedwojennych antysemitów były powszechne, podkreślał, że „procent ludzi podobnych do Braci X jest znikomy" (s. 149).

Autor Spowiedzi także bardzo krytycznie, bez żadnej taryfy ulgowej, pisze o zachowaniu ludności żydowskiej. Tylko dla przykładu przytoczę kilka cytatów. Oto uwagi ogólne Perechodnika na temat (każdego?) Żyda: „,...] co by Żyd nie zrobił, żeby żyć o godzinę dłużej” (s. 68); „[...] każdego poszczególnego Żyda ogarnęła psychoza: ja jestem czymś lepszym, mnie nie wysiedlą" (s. 156). Jeszcze jeden dłuższy cytat:

Życie w getcie było dość dziwne, niczego nie brakowało, wszystko za pieniądze można było dostać, z Rosji nadchodziły bogate paczki żywnościowe dla krewnych. Bogaty żył, ubierał się, jadł, pił, nie obawiając się zupełnie wysyłki do obozu, za pieniądze można było zawsze się wykupić, z chwilą gdy biedny dosłownie puchł z głodu i umierał na oczach ludzi. (s. 30)

Przytoczone tu ogólne opinie są oczywiście krzywdzącymi generalizacjami i nie mogą ich usprawiedliwiać nawet osobiste doświadczenia piszącego, który na przykład na własne oczy obserwował i takie oto zachowania: „[...] po akcji nastąpiło wielkie rozprężenie moralne. Nikt już się z niczym nie liczył, wiedząc, że i tak wkrótce zginie. Niektórzy chłopcy po akcji mieli stosunki z dziewczynkami, które nazajutrz miały być rozstrzelane" (s. 300). Trudno zaakceptować także przekonanie Perechodnika, który uważa, że - obok niemieckiego ludobójstwa - odpowiedzialna za Zagładę była religia żydowska, i to religii przypisuje „całą winę”. „Nie można korzystać z gościnności innych narodów i uważać się za naród wybrany, naród mądrzejszy. Modlić się codziennie: «Tyś nas wybrał pośród innych narodów, pokochałeś nas»" (s. 256).

\section{Kultura dawna w tekście o Zagładzie}

Przywołane powyżej cytaty wskazują, iż autor Spowiedzi posiadał zarówno bardzo dobrą znajomość polszczyzny (tekst napisany

szej jest zapis: „Żyd, gestapowiec”, a w przypisie czytamy: „Nie gestapowiec, lecz agent gestapo” (zob. C. Perechodnik, Czyja jestem morderca??, s. 239, 325). We współczesnych opracowaniach pojawią się takie określenia jak „żydowski agent gestapo” czy „,agenci żydowskiego gestapo” (zob. m.in. M.J. Chodakiewicz, Żydzi i Polacy 1918-1955. Wspótistnienie - Zagtada - Komunizm, Warszawa 2011, s. 161, 201). 
jest prostym i jasnym językiem), jak i znaczną wiedzę literacką (w Spowiedzi pojawia się wiele cytatów z literatury europejskiej i polskiej). Maria Janion pisze, iż „czujemy obecny na wielu stronach oddech polskiej poezji romantycznej” ${ }^{23}$. Perechodnik sięga między innymi po utwory Juliusza Słowackiego (s. 73, 167), Adama Mickiewicza ${ }^{24}$ (s. 101, 238), a także na przykład Adama Asnyka - Sonet XXIX (s. 73) czy Do mtodych (s. 229). W miejscu tym musi pojawić się zasadnicze dopełnienie opinii, którą tu przytaczam: dla Perechodnika nie tylko polska poezja romantyczna jest punktem odniesienia, autor doskonale porusza się po całym obszarze kultury europejskiej, przede wszystkim łacińskiej i romańskiej, a także literatury staropolskiej, szczególnie często przywoływane są fragmenty utworów Jana Kochanowskiego. Znajomość łacińskiej kultury śródziemnomorskiej potwierdzają pojawiające się wielokrotnie w tekście Spowiedzi cytaty. Jednocześnie, co wydaje się cechą charakterystyczną pisarstwa Perechodnika, sentencje i inne zaczerpnięte fragmenty są zarówno dość swobodnie przekształcane, jak i umieszczane często w kontekstach dalekich od wzorów wyznaczonych przez tradycyjną interpretację. Na przykład autor Spowiedzi cytując sentencję z pieśni Horacego Non omnis moriar (III, 30, w. 6) ${ }^{25}$, umieszcza ją w kontekście zarówno nieśmiertelności tworzonej przez przychodzące po sobie kolejne pokolenia, jak i wiary (okazało się, że całkowicie złudnej) w utrwalone w kulturze europejskiej „dogmaty polityczne”:

[...] wierzyłem, muszę zaznaczyć, we wszystkie przyjęte dogmaty polityczne. Byłem też bardzo przejęty tragiczną śmiercią szwagra, ale też zazdrościłem mu, że po sobie zostawił małego synka. Synek urodził się 21 października 1939 roku i liczył trzy tygodnie w momencie śmierci ojca swego. Również z żoną podzielaliśmy kult Chińczyków dla przodków, a tym samym chęć posiadania potomstwa, które i zwykłemu człowiekowi pozwala z dumą powiedzieć: Non omnis moriar. Zresztą kobietom, tym bardziej dzieciom, na pewno nic stać

23 M. Janion, op.cit., s. 265.

${ }^{24}$ Na twórczość Mickiewicza i Słowackiego powołuje się także inny żydowski autor pamiętnika Baruch Milch (Testament, Warszawa 2012, s. 39): „Było to tak, jak w swoim czasie pisał Juliusz Słowacki: że Polacy, gdy odzyskają wolność, stają się niewolnikami zła. Zapomniano też przestrogę daną przez Adama Mickiewicza w Ksiegach narodu i pielgrzymstwa polskiego, mówiąc, że o ile Polacy w uzyskanej ojczyźnie nie uszanują wolności innych, prędko sami ją stracą".

${ }_{25}$ Korzystam z wydania: Kwintus Horacjusz Flakkus, Dzieła wszystkie, t. 1: Ody i epody, tekst łaciński do druku przygotował, wyboru przekładów dokonał, przedmową, życiorysem poety, wersyfikacją i komentarzem opatrzył O. Jurewicz, Wrocław 1986. 
się nie może, wojna się wkrótce skończy. Dość że żona moja zaszła w ciążę, spodziewaliśmy się dziecka w sierpniu 1940 roku, a wtedy i śladu po Niemcach wszak nie będzie. (s. 26)

Zacytowana sentencja pochodzi z pieśni Horacego znanej pod tytułem (fragment incipitu) Exegi monumentum, stanowiącej zamknięcie i podsumowanie trzech ksiąg ód. W kulturze europejskiej pieśń ta wyznaczyła topiczną tradycję wskazującą na unieśmiertelniającą funkcję poety i jego twórczości ${ }^{26}$. Perechodnik, świadomy klasycznej europejskiej tradycji interpretacyjnej, dostosował ją do potrzeb „zwykłego człowieka”, który nie jest poetą i może zapewnić sobie nieśmiertelność nie przez własną twórczość, ale przez swoich następców, kolejne pokolenia członków rodziny - dzieci, wnuków i prawnuków.

Jedną z cech pisarstwa Perechodnika jest to, że niektóre sentencje powtarza kilkakrotnie, również tę zaczerpniętą z pieśni Horacego. Pamiętnikarz powraca do niej przy opisie szczególnie dramatycznych chwil, kiedy to w obliczu zagłady niektóre Żydówki decydują się na zażycie luminalu:

Ty, wielka pani [chodzi o inżynierową Skotnicką - M.S.], szlachetna kobieta, ach uśmiechasz się, Non omnis moriar - szeptają Twe wargi. Racja, zdążyłaś w wojnie wysłać syna i córkę do Palestyny. Syn Twój na pewno walczy w szeregach Anglii, pomści Cię, córka zaś Twa ukończyła technikum w Hajfie, da Bóg, wyjdzie za mąż, będzie miała dzieci, którym nada imię po Tobie. Wargi się Twe uśmiechają. Non omnis moriar, Twego rodu Niemcy nie wyplenią. (s. 72)

I w tym przypadku odczytanie sentencji zostało dostosowane do „zwykłych ludzi”, w kontekście następstwa kolejnych pokoleń, które gwarantują nieśmiertelność przodkom, ciągłość rodziny i pomszczenie krzywd. Analizowany tu cytat można także potraktować jako przesłanie ironiczne: kobieta, popełniając samobójstwo, ulega złudzeniom, które mają nadać sens temu czynowi.

W związku z przesiedleniem ludności żydowskiej do getta i panującymi tam, przynajmniej na początku, warunkami Perechodnik przywołuje sentencję z Cycerona (Paradoksy stoickie 1, 1, 8) - Omnia mea mecum porto:

${ }^{26}$ E.R. Curtius, Poezja jako unieśmiertelnienie, w: idem, Literatura europejska i łacińskie średniowiecze, przeł., oprac. A. Borowski, Kraków 1997, s. 495-498. Zob. też A. Wójcik, Talent i sztuka. Rzecz o poezji Horacego, Wrocław 1986, s. 332-333. 
Getto rozpoczęło się dość niewinnie, nie było ogrodzone, wolno było wychodzić, obszar był dość duży, mieszkań ani żywności nie brakowało. [...] Widząc, że wojna się nie kończy i żeby być wolnym od łapanek do obozów, wstąpiłem w szeregi Ghetto-Polizei w lutym 1941 roku. Jedną dobrą stroną getta, według ówczesnego pojęcia, było to, że Niemcy po getcie się nie kręcili, ustały rabunki oraz rewizje. Jak czegoś potrzebowali, to zwracali się do Judenratu, który im wszystko dostarczał, toteż wycofałem moje rzeczy od Alchimowicza i omnia mea mecum habram w małym pokoju, gdzie spędziłem zimę i lato 1941 we względnym spokoju, opiekując się i wychowując moją małą Alinkę. (s. 29-30)

Tym razem, mimo iż Perechodnik zmienił nieco brzmienie sentencji, to jednak użył jej zgodnie z jedną z dwóch zasadniczych interpretacji funkcjonujących $w$ tradycji europejskiej. Sentencję tę stosowano (stosuje się) zawsze w opisie losu wygnańca (i jego mienia) uciekającego z ojczyzny przed wkraczającym wrogiem. Druga interpretacja odnosi się do losu filozofa, artysty, który nie jest przywiązany do rzeczy ziemskich, a cały swój dobytek, czyli bogactwo duchowe, ma zawsze ze sobą i dlatego w razie potrzeby zawsze może przemieszczać się z miejsca na miejsce ${ }^{27}$. W innym fragmencie pamiętnika Perechodnik powtarza tę myśl, tym razem jednak w funkcji ironicznej skierowanej do wszystkich Żydów: „,...] przede wszystkim nie wolno być niewolnikiem towaru, złotych kajdanów nie wolno sobie samemu zakładać na ręce. Omnia mea mecum porto, takie powinno być hasło każdego człowieka, a przynajmniej każdego Żyda, i cały towar nie powinien przekraczać 20 kilo" (s. 299). Ten niewielki bagaż - często jeszcze mniejszy, zgodnie z rozporządzeniami Niemców - mógł zostać zabrany przez Żydów wysiedlanych do miejsc Zagłady. Gorzka ironia polega tu na tym, że tylko pozornie gwarantował on swobodę podróżowania, zapewniając swego rodzaju bezpieczeństwo. Tak naprawdę związany był z podróżą na śmierć.

Podobnie ironiczny wydźwięk ma stwierdzenie dotyczące warunków życia ukrywających się u Geni: „,Vivereparvo - to jest nie lada sztuka w życiu”. Oto dłuższy cytat, który pozwoli zrozumieć znaczenie sentencji w odpowiednim kontekście:

Genia ma kilka dobrych stron charakteru. Przede wszystkim jest bardzo delikatna a dumna zarazem. Inna rzecz, że duma jej graniczy $\mathrm{z}$ arogancją, prócz tego jest strasznie zimna i sztywna, toteż będąc tak

${ }^{27}$ M.T. Cicero, Paradoksy stoików, przeł. W. Kornatowski, w: idem, Pisma filozoficzne, t. 3, Warszawa 1961, s. 450. 
długo u „naszej pani” nie przywiązała jej do siebie uczuciowo. Genia nigdy o nic nie prosi i sama bez pozwolenia niczego nie weźmie. [...] Ma zaś żelazny organizm, który może przetrzymać „,wikt” u ,naszej pani”: 5 deka chleba na cały dzień, no i w ogóle umie zadowolić się małymi potrzebami. Vivere parvo - to jest nie lada sztuka w życiu. (s. 283-284)

Sentencja ta jest przekształceniem wersu pieśni Horacego (II, 16, 13): Viviturparvo bene $e^{28}$, przy czym antyczny poeta wskazuje drogę życia swojemu bogatemu przyjacielowi Grosfusowi. Oczywiście czym innym jest swobodny wybór „skromnego życia”, a czym innym - tu ujawnia się ironiczne zacięcie Perechodnika - przymuszenie do biedowania wynikające $\mathrm{z} \mathrm{ka-}$ prysów „naszej pani”. Ukrywający się Żydzi często w wyniku twardej konieczności, a nie z dobrowolnego wyboru, wiedli bardzo skromne życie, cierpieli głód i szykany.

W związku z rozpaczą skazańców Perechodnik pisze: „Id clamor caelo! Ale cóż tam jest w tym niebie? Jest że Bóg? Istnieje jakaś sprawiedliwość wyższa, która rządzi tym światem. To czemuż milczy? Czemuż gromy nie spadają z nieba? Dlaczego się ziemia nie otworzy, aby pochłonąc katów, morderców dzieci, kobiet, starców?" (s. 109). Cytat łaciński pochodzi z Eneidy Wergiliusza: „[...] okrzyk zatrwożeni w niebiosa bije” $(\mathrm{V}, 451)^{29}$. Refleksja dotycząca „pustego Nieba” jest jedną z fundamentalnych myśli towarzyszących Zagładzie i silnie oddziałuje na kulturę (filozofię, literaturę) w czasach po Zagładzie. Mam tu przede wszystkim na myśli nurt współczesnej refleksji filozoficznej stworzony wokół zdania Nietzschego „Bóg umarł”, nurt, który jest diagnozą poważnego kryzysu moralnego i światopoglądowego wynikającego ze skutków wielkich europejskich totalitaryzmów wieku XX. Znaczna część pamiętnika Calka Perechodnika została poświęcona opisowi zapaści moralnej wśród przedstawicieli trzech narodów. O kryzysie podstawowych wartości etycznych, który dotknął polskich urzędników magistratu, Perechodnik pisze: „Przede mną siedzą urzędnicy Polacy, którzy wciąż dopytują się, jak to odbyła się akcja. Prawdopodobnie mają podobne uczucie rozmawiając z Żydem, jakie odczuwał Neron w cyrku rzymskim. Ave Caesar, morituri te salutant' (s. 139) 30. Calek Perechodnik

${ }^{28}$ Korzystam z wydania: Kwintus Horacjusz Flakkus, Dzieła wszystkie, t. 1: Ody i epody, s. 197.

29 Przekład polski podaję za: Publiusz Wergiliusz Maro, Eneida, przeł. T. Karyłowski, oprac. S. Stabryła, Wrocław 1981, s. 138.

$3^{\circ}$ Emanuel Ringelblum nawiązał do tej łacińskiej sentencji, kiedy w $1942 \mathrm{r}$. pisał: „Żydzi są morituri - skazani na śmierć, wyrok śmierci, choć odroczony 
odczuł na własnej skórze zjawisko niedostrzegania przez tychże urzędników Żydów jako żywych ludzi. Raczej widziano w nich jak to określił Emanuel Ringelblum - „nieboszczyków na urlopie" ${ }^{\text {I }}$.

W dzienniku Perechodnika znajdujemy też grupę cytatów i sentencji (najczęściej pochodzących z Biblii), które nawiązują do relacji między Polakami a Żydami, przy czym odnoszą się one nie tyle do relacji jednostkowych, ile do grupowych. W związku $\mathrm{z}$ różnymi reakcjami ludności polskiej na zgromadzenie Żydów na placu w Otwocku przed deportacją do obozu Zagłady autor przywołuje znaną sentencję modlitewną requiescent in pacem (requiescat in pace) zaczerpniętą z Księgi Psalmów $(4,9)$ a będącą popularną inskrypcją nagrobną ${ }^{22}$ („Niech spoczywa w pokoju”), ten kontekst uruchamia całą chrześcijańską tradycję tanatologiczną:

[...] patrzysz na Polaków, którzy jadą w przepełnionych wagonach elektrycznych i oglądają po raz ostatni Żydów. Jedni są na pewno szczerze zadowoleni i żartują, jak grzecznie wyglądają Żydzi na placu, jak stado baranów, drudzy zaś pochylają głowy, w milczeniu robią znak Krzyża Świętego, requiescent in pacem - szepcą ich usta. Wszak trupów widzą już przed sobą. (s. 70)

W przywołanym tu cytacie znajduje się nawiązanie do jeszcze jednego bardzo popularnego, choć budzącego kontrowersje, powiedzenia: „,[Żydzi szli na śmierć] jak stado baranów [prowadzonych na rzeź]”. Inne wersje tego powiedzenia to: „jak owce/ barany/jagnięta na rzeź”. Sama fraza jest prawdopodobnie przekształceniem cytatu z Księgi Izajasza $(53,7)$ : „Jak baranek na rzeź prowadzony, / jak owca niema wobec strzygących ją [...]”. Powiedzenie to zarówno w czasie Zagłady, jak i współcześnie budziło - budzi - wiele zastrzeżeń; podważa się jego prawdziwość, wskazuje się wręcz na zawarty w nim antysemicki charakter. W formie uogólnienia odnoszącego się do „wszystkich Żydów” powiedzenie to jest krzywdzące i niesprawiedliwe. Jednakże wystarczy przejrzeć materiały z Archiwum Ringelbluma, żeby się przekonać, jak często sami Żydzi przywołują to porównanie:

na nieznany czas, został jednak wydany”. Archiwum Ringelbluma. Dzień po dniu Zagtady, Warszawa 2011, s. 206.

${ }^{3 \mathrm{I}}$ Zob. E. Ringelblum, Stosunki polsko-żydowskie w czasie drugiej wojny światowej. Uwagi i spostrzeżenia, oprac., wstęp A. Eisenbach, Warszawa 1988, s. 65 .

$3^{2}$ Ukrywający się Żydzi często z potrzeby lektury czytali religijną literaturę chrześcijańską, w tym katechizm i Nowy Testament - zob. B. Milch, op.cit., s. 232. 
„Tłum czynił wrażenie zrezygnowanej masy, pogodzonej z losem. Porównanie ze stadem owiec pędzonych na rzeź, mimo swojej banalności, jest jednak najwłaściwsze" 33 .

Trzeba też zauważyć, że w Spowiedzi niektóre cytaty łacińskie pełnią tylko funkcję ozdobną, są swego rodzaju świadectwem erudycji, zakorzenienia autora w antycznej kulturze śródziemnomorskiej, jego sprawności stylistycznej: Sapienti sat (s. 45)34 (pełna wersja: Verbum sapienti sat) lub też znajomości popularnych powiedzeń: vox populi (s. 47)35(pełna wersja: Vox populi, vox Dei); w innym miejscu Perechodnik przywołuje sentencję: periculum in mora (s. 49) ${ }^{36}$.

Calek Perechodnik, odwołując się do literatury staropolskiej - jak już pisałem - przywołuje przede wszystkim utwory Jana Kochanowskiego. Autor Spowiedzi cytuje i dopowiada fragment z Trenów 37 : „Kochanowski w bólu swoim pisał: «Kogo [kiedyś - C.P..$\left.^{8}\right]$ dobroć przypadku złego uchowała» [Tren XI, w. 4 - M.S.]; ja pójdę dalej pisząc: «Kogo kiedyś złość przypadku dobrego uchowała»" (s. 232). Od czasów pierwszej edycji Treny stały się jednym z najważniejszych tekstów w polskiej kulturze funeralnej, były wielokrotnie naśladowane i trawestowane, także współcześnie, stały się swoistym hipertekstem. Opanowały polską wyobraźnię związaną z umieraniem i śmiercią, stając się kopalnią cytatów, które zdominowały napisy nagrobne. W tym kontekście może dziwić, że Calek Perechodnik, który stracił małą córeczkę, tylko raz odwołuje się do hipertekstu Jana Kochanowskiego, jednocześnie odwracając znaczenie: „dobroć przypadku złego” została zastąpiona przez „złość przypadku dobrego”. Zabieg ten jest wyraźnym dowodem, iż po pierwsze, Perechodnik uważał, że „nie ma sprawiedliwości wyższej na świecie”; i po drugie, że rozumiał swoją sytuację egzystencjalną jako diametralnie różną od sytuacji poety - ojca z Trenów.

33 Archiwum Ringelbluma, s. 171. Inne strony, na których występuje to porównanie: 148, 206, 207, 219.

34 „Porzekadło z Plauta: Pers 4, 7, 19; podobnie u Terencjusza w komedii Formio 3, 3, 8". Thesaurus. Skarbiec lacińskich sentencji, przystów i powiedzeń w literaturze polskiej, zebrał, oprac. M. Korolko, Warszawa 1997, s. 441.

35 Sentencja została powtórzona na s. 303.

${ }^{6}$ Jest to sentencja pochodząca z: T. Liwiusz, Dzieje Rzymu od załozienia Miasta, ks. XXXV-XL, przeł., oprac. M. Brożek, komentarz M. Brożek, J. Wolski, Wrocław 1981, s. 217 (38, 25, 13). Inne przykłady użycia sentencji i zwrotów lacińskich w funkcji czysto stylistycznej: s. 159, 183, 282.

37 Korzystam z wydania: J. Kochanowski, Treny, oprac. M.R. Mayenowa et al., Wrocław 1983.

$3^{8}$ Wydaje się, iż Perechodnik, cytując z pamięci, połączył dwa wersy: „Kogo kiedy pobożność jego ratowała?/ Kogo dobroć przypadku złego uchowała?” (w. 3-4). 
Autor Spowiedzi odwracał nie tylko sens cytatów, zamieniał też znaczenie popularnych sentencji, choćby w celu ironicznego przedstawienia postaw niektórych Polaków: „,...] zostawmy sprawy materialne, to są brudne sprawy, nie wypada w ogóle o nich mówić: „pecunia olet” [właśc. pecunia non olet - M.S.]. Zresztą skąd Żydzi wzięli ten majątek? A bo nie z ziemi polskiej..., nadszedł czas, zwrócili dług Polakom, wszystko jest w porządku, nie ma też o czym mówić” (s. 146-147). Perechodnik, odwracając znaczenia cytatów i sentencji, doskonale mieści się $\mathrm{w}$ tradycji poezji czarnoleskiej, wszak powszechnie, przynajmniej wśród ludzi wykształconych, znane było odwrócone przysłowie Jana Kochanowskiego: „Polak [...] i przed szkodą i po szkodzie głupi”. Autor Pieśni zastąpił ironicznie używany w przysłowiu epitet - „mądry” dosłownym - „głupi” i rozszerzył zakres obowiązywania "głupoty”: „i przed szkodą” ${ }^{39}$. Schematycznie zabiegi odwracania znaczeń przysłów (cytatów i sentencji) można zapisać na dwa sposoby, tak:

$$
\mathrm{P} \rightarrow \sim \mathrm{P}
$$

lub tak:

$$
\sim \mathrm{P} \rightarrow \mathrm{P}
$$

Odwracanie znaczeń przysłów, cytatów, sentencji mocno powiązane jest $\mathrm{z}$ ironią, mówiąc dokładniej: odwracanie wykorzystuje opozycję między znaczeniem ukrytym a wypowiedzianym wprost przesłaniem. Musimy pamiętać, że na przykład grecki teoretyk retoryki Anaksymenes definiuje ironię następująco: „Mówić coś udając, że się tego nie mówi, lub mówić o jakiejś rzeczy używając przeciwstawnych do niej nazw - oto czym jest ironia" $(21,1)^{40}$. Nas tu szczególnie interesuje drugie znaczenie ironii, które Anaksymenes ilustruje przykładem: „Okazuje się, że ci czcigodni panowie tyle krzywd wyrządzili swym sprzymierzeńcom, my zaś, niegodziwcy, staliśmy się dla nich sprawcami tak wielu dóbr” ${ }^{4}$. Ironicznie zostały użyte określenia „czcigodni” i „niegodziwcy”.

W innym miejscu dziennika, opisując losy swojego ojca, autor Spowiedzi przytacza cytat z Pieśni śreviętojańskiej o Sobótce:

39 O odwracaniu znaczenia sentencji pisałem w: M. Skwara, Seneka w polskich kazaniach pogrzebowych XVII wieku, w: Watki neostoickiew literaturzepolskiego renesansu i baroku, red. P. Urbański, Szczecin 1999, s. 261 i n.

$4^{\circ}$ Retoryka dla Aleksandra, przeł. H. Podbielski, w: Arystoteles, Dzieta wszystkie, t. 6, Warszawa 2001, s. 530. Zob. R. Turasiewicz, Problemy antycznej ironii, „Zeszyty Naukowe UJ DCXLVII. Prace Historycznoliterackie” 1983, z. 47 , s. 56 .

${ }^{4}$ Retoryka dla Aleksandra, s. 531. 
Tym razem był już zupełnie legalnie zameldowany, nawet żandarmeria skontrolowała jego Kenkartę, mógł w tej wsi śmiało przeżyć wojnę, otoczony powszechnym szacunkiem i pod troskliwą opieką swej gospodyni. Mógł żyć i spokojnie żyć, i powtarzać za Kochanowskim: Wsi spokojna, wsi wesola/ który glos twej chwale zdoła, kto twe wywczasy, kto pożytki/ może wspomnieć zaraz wszytki. Cztowiek na twej pieczy uczciwie/ spokojne ma życie $i$ bezpieczne bytowanie. (s. 253)

Początkowy fragment pieśni Panny XII w tekście Kochanowskiego brzmi:

Wsi spokojna, wsi wesoła,

Który głos twej chwale zdoła?

Kto twe wczasy, kto pożytki

Może wspomnieć zaraz wszytki?

Człowiek w twej pieczy uczciwie

Bez wszelakiej lichwy żywie;

Pobożne jego staranie

I bezpieczne nabywanie ${ }^{42}$.

Perechodnik odwołuje się do kulturowej wizji wiejskiej arkadii (locus amoenus) ${ }^{43}$, która wyraźnie przeciwstawiona została miastu jako miejscu ciągłego zagrożenia. To, że Perechodnik dostrzegł w polskiej wsi miejsce przyjazne dla ukrywającego się Żyda, jest znaczące współcześnie, gdy niektórzy historycy Zagłady starają się dowieść, iż polska wieś, a szczególnie jej mieszkańcy, stanowili tylko i wyłącznie śmiertelne zagrożenie dla przebywających tam Żydów. Na przykład Jan Tomasz Gross jest przekonany, że dla ludzi, którzy uciekli z getta, transportu lub obozu zagłady, Polacy katolicy, mieszkańcy wsi byli większym zagrożeniem niż Niemcy, a polska wieś była gorszym miejscem niż obóz ${ }^{44}$. Z kolei Barbara Engelking-Boni sformułowała taką oto opinię: „,...] dla Żydów, którzy próbowali się ratować, zagrożeniem byli w pierwszym rzędzie Polacy katolicy, nie Niemcy. To nie Niemcy biegali po wsiach i wyciągali Żydów z kryjówek w lasach. Niemcy oczywiście zabijali, ale ktoś im Żydów wskazywał albo przyprowa-

$4^{2}$ J. Kochanowski, Pieśń śrwiętojańska o Sobótce, w: idem, Pieśni, oprac. M.R. Mayenowa et al., Wrocław 1991, s., w. 1-8.

43 Zob. E. R. Curtius, Rozkoszne miejsce, w: idem, Literatura europejska i łacińskie średniowiecze, s. 202-206.

44 Zob. m.in. J.T. Gross, I. Grudzińska-Gross, Złote żniwa. Rzeczo tym, co się działo na obrzeżach Zagtady Żydów, Kraków 2011. 
dzał" ${ }^{45}$. W wypowiedzi tej manipulacja jest wielopiętrowa: po pierwsze, Polacy byli gorsi niż Niemcy; po drugie, bezpieczniej było w getcie, obozie niż na wolności, czyli po tzw. aryjskiej stronie, na przykład na wsi; po trzecie wreszcie, Polacy-katolicy polowali na Żydów, a Niemcy ich tylko (?!) rozstrzeliwali, „ale ktoś im Żydów wskazywał albo przyprowadzał". Ukryty wniosek tego rozumowania entymematycznego jest taki: Niemcy nie zabijaliby Żydów, gdyby Polacy ich nie dostarczali, czyli winni mordowania Żydów są Polacy, a nie Niemcy. Barbara Engelking-Boni wydaje się nie dostrzegać istnienia niemieckich obozów zagłady, hitlerowskich masowych mordów, gett, eksterminacji.

Musimy pamiętać - powracam do bohatera Spowiedzi - że „ojciec” narratora pamiętnika dociera do wiejskiej arkadii po wielu nieudanych próbach znalezienia sobie bezpiecznego miejsca schronienia, po długiej „wędrówce”. Oszer Perechodnik był $\mathrm{w}$ owej arkadii tylko gościem, nie był stałym jej mieszkańcem, dlatego też i tym razem opuszcza to miejsce z własnej „winy”wyjaśnienie Calka Perechodnika ma bez wątpienia charakter ironiczny: „Mógł spokojnie żyć, gdyby nie drobny fakt: sam uwierzył, że jest Polakiem, rdzennym Polakiem z krwi i kości. Więc jeśli jemu mogło się udać, to czemu nie przywieść tu żony swojej, wszak na kobiecie na pewno nikt się nie pozna” (s. 254). Arkadia to także - zgodnie z nowożytną interpretacją - kraina, w której pojawia się śmierć (zob. Et in Arcadia ego) ${ }^{46}$, w tym sensie także wiejska arkadia w czasach wojny i Zagłady była miejscem niebezpiecznym dla wszystkich mieszkańców.

Pora na podsumowanie. O czym świadczą tak liczne cytaty w tekście Spowiedzi? Po pierwsze, o dobrym wykształceniu humanistycznym Calka Perechodnika, jego głębokim osadzeniu w kulturze śródziemnomorskiej i literaturze polskiej. Opisując swoje życie w czasach Zagłady, Perechodnik odwołuje się do znanego sobie dorobku kultury. Próbując oswoić, a więc zrozumieć to, co dzieje się wokół, autor pamiętnika korzysta z dostępne-

45 Sen o Zagtadzie. Jak biedni Polacy patrza na getto [z B. Engelking-Boni rozmawia M. Okoński], „,Tygodnik Powszechny” 2005, nr 35. Przedruk w: Przeciw antysemityzmowi, wybór, wstęp, oprac. A. Michnik, t. 3, Kraków 2010, s. 419.

${ }^{46}$ Zob. m.in.: J.M. Rymkiewicz, Myśli różne o ogrodach. Dzieje jednego toposu, Warszawa 1968, s. 58 i n.; E. Panofsky, Et in Arcadia ego. Poussin i tradycja elegijna, przeł. A. Morawińska, w: idem, Studia z bistorii sztuki, wybór, oprac., posłowie J. Białostocki, Warszawa 1971, s. 324-342. 
go mu repertuaru narzędzi kultury. Sięganie do skarbca kultury europejskiej (nawet przez zaprzeczenie) w przedstawieniach zdarzeń związanych z wojną, okupacją i Zagładą jest zjawiskiem powszechnym. Oto na przykład jeden z mieszkańców Warszawy (Wojdysławski) zanotował we wrześniu 1939 r.: „Umarł Dante i nie zmartwychwstanie, ale - gdyby nawet był - i on nie oddałby, nie odmalowałby tych tysięcy trupów ludzi, koni i domów, które wszystkie w niemej skardze leżały nieruchomo nagie, niezakryte, groźne. Wszystkie zdawały się niebu i ziemi zadawać jedno i to samo pytanie: Za co, w imię czego?" "47. Perechodnik nie jest artystą pisarzem, nie jest także - choć tak próbują interpretować Spowiedź niektórzy współcześni badacze - człowiekiem ponowoczesnym, nie kwestionuje możliwości języka jako narzędzia opisu świata i skutecznego porozumiewania się (nie podważa funkcji referencjalnej języka). Pisarze, poeci, inni ludzie pióra doskonale zdawali sobie sprawę z tej nieprzystawalności języka słowa - do rzeczywistości w czasach Holocaustu. Na przykład pisarka Gustawa Jarecka (?) w listopadzie 1942 r. zanotowała: „Pragnienie pisania jest dziś równie silne, jak odraza do słów. Nienawidzimy ich, bo zbyt często pokrywały pustkę albo nikczemność. Pogardzamy nimi, bo są blade wobec uczuć, które nami targają. A przecież niegdyś słowo oznaczało godność ludzką i było czymś najlepszym, co człowiek posiadał, narzędziem porozumienia między ludźmi” 48 .

Praktycznie jedynymi znakami dostrzegania przez Perechodnika dystansu i rozziewu między językiem (kulturą) a otaczającą go rzeczywistością są ironia figuratywna i silnie $\mathrm{z}$ nią spowinowacony chwyt odwracania znaczenia cytatów i sentencji. Jednakże - chciałbym to jeszcze raz podkreślić - ironia rozumiana jest w Spowiedzi nie jako zasada konstruująca cały tekst, ale przede wszystkim jako jeden z tropów myślowych. Chyba tylko te dwa zabiegi - odwracanie znaczeń cytatów i sentencji oraz ironia figuratywna - wskazują, że Perechodnik dostrzegał istnienie „niewspółmierności” między światem kultury a otaczającą go rzeczywistością.

\footnotetext{
47 Archiwum Ringelbluma, s. 19.

$4^{8}$ Ibidem, s. 212.
} 


\section{MAREK SKWARA}

\section{Text in Culture, Culture in Text. The Latin Tradition and Old-Polish Literature in Calek Perechodnik's Spowiedź [Confession]}

The article analyses and interprets the apothegms and quotations from ancient and old-Polish literature in one of the most important testimonies of the Holocaust in world literature. In Polish criticism, there are few discussions of Perechodnik's journal, and the existing articles are controversial because of their biased interpretations, which, in the present author's opinion, are often manipulatory. It seems that the Polish intepretators of Spowied źtry, contrary to the author's clear intention, to inscribe the text in the current controversies between Poles and Jews, while disregarding the third nation (Germans), and to turn Perechodnik into a postmodern author, because it allows for suspension of ethical rules. The greatness and tragedy of the author, however, stand for their own without such manipulations.

Keywords: Holocaust, journal, Polish-Jewish-German relations during the Holocaust, manipulations, Latin and Old-Polish tradition, apothegm and proverb.

Marek Skwara - profesor doktor habilitowany, kierownik Zakładu Literatury Staropolskiej i Oświeceniowej US. Zainteresowania badawcze autora dotyczą: dawnej i współczesnej tanatologii, ze szczególnym uwzględnieniem związków literatury z plastyką, retoryki oraz wszelkiego rodzaju manipulacji (zarówno w publicystyce, jak i w nauce). 